\title{
Investigation of College English Teaching and Teaching Reform in University
}

\author{
Wu Xuejing \\ Foreign Languages Teaching and Research Department \\ Jilin University of Finance and Economics
}

\begin{abstract}
- along with our country education reform, University Chinese College English teachinghas also undergone changes and the corresponding development, and achieved certain results.University English teaching to cultivate students' comprehensive ability of using English and the ability of autonomous learning, challenges to deal with the teaching of colleges and universitiesare facing to a thorough understanding of the current situation, based in the university English Teaching in Universities of our country, for further improving. This paper will make an investigation on the current situation of English Teaching in Colleges and universities of our country University analysis, discussion on the reform of university English teaching and the direction of development.
\end{abstract}

Keywords- university English; investigation; teaching reform; development direction

\section{INTRODUCTION}

With the development of economic globalization, international exchanges and cooperation in China is increasingly close, English as the main tool of foreign exchange, the learning andteaching has attracted more and more attention. University English courses in Colleges and universities in China, its purpose is to train and improve students' comprehensive ability of using English, improve the competitiveness of college graduates in china. In the basis of fully understanding the current situation of College English teaching, appropriate for the reform of College English teaching, improve teaching quality.

\section{INVESTIGATION OF THE PRESENT SITUATION OF} ENGLISH TEACHING INCOLLEGES OF THE UNIVERSITY

\section{A. The contents of investigation}

To sum up the successful experience in the College English teaching reform, to better adapt to the curriculum requirements, deepening of College English teaching reform, the Ministry of education in 2009 -2010 years of English teaching situation of National University for a comprehensive and systemic investigation. The main contents include the investigation of theimportance of the course, teaching objectives and contents; curriculum; teaching mode and teaching methods; application and development of multimedia and network evaluation; the construction technology; teaching teachers; teaching conditions and teaching environment (Ceng Xiaoshan, 2013). The survey uses the way is the network questionnaire and sample survey, a total of 550 colleges and universities participated in the survey, the survey covers a wide area,especially.

\section{B. The results and analysis}

The importance, teaching objectives and content of courses. The survey results show that, most of the colleges and universities should be to strengthen university English course in Colleges and universities in the status, further improve the university English teaching level, fewuniversities think university English curriculum status should be reduced accordingly. More than half of the university are to some extent to organize the university English Teaching in accordance with the requirements of the new curriculum reform, and to develop the corresponding teaching syllabus, these colleges and universities include both engineeringcolleges, including non

engineering college. This shows

that the university English teaching reform has been launched in the institutions. Almost all colleges and universities will beimproved and the cultivation of the students' comprehensive ability of using English as the main teaching goal of the school, the teaching content, listen, say, read these three skills are considered as the main content of the basic skills of English in university. The course. The curriculum according to the requirements of the new curriculum reform in Colleges and universities as well as the actual situation of their own to arrange, design a university Englishcurriculum system with their own characteristics, make students of different levels in universitystage English ability fully and comprehensively improve (Sui Xiaobing, 2013). According to the results of the survey, University English course in Colleges and universities in China are generally divided into two parts, one part is a compulsory course, is part of the elective coursesand required courses, credit ratio is gradually reduced. In the curriculum when the school takethe unified form, a part of College hope can set the university English curriculum with the actual needs of professional. The teaching mode and teaching method. University English Teaching in improving students' ability of using English and also advocates the cultivation of students' autonomous learning ability. Survey results show that, in order to ensure a comprehensive grasp of the basic skills of the students, teaching mode can adopt the teaching types. Different universities, said the listening, reading, writing, translating five skill emphasis and proportion is not the same, the 
teaching mode and teaching method is the traditional teaching modecombined with modern science and technology, the combination of teaching and teachers face to face network autonomous learning. The application and development of multimedia and network technology. The results from this survey data show, University College English multimedia teaching almost all are commonly used for multimedia and network technology in teaching, but the application software is provided by the school outside of the press, too dependent on external technical support, the lack of independent research and development ability. Teaching assessment. Teaching evaluation is an important content in College English teaching, teaching evaluation to handle all aspects of relations, the assessment for each link ofteaching process, in order to make judgments about the teaching effect. The detailed investigation, the investigation teaching evaluation for colleges and universities showed thatmost of the colleges and universities will be the student classroom performance and homeworkand test results as an important basis for evaluation of teaching, but teaching assessment ability of autonomous learning and network platform in the students also reference rarely. On the construction of teachers' team. In participating in the survey of colleges and universities, the construction of teachers compared with the past has improved to a large extent, the number of teachers have master degree and $\mathrm{PhD}$ degree and the ratio is increasing year by year, the academic structure of the teachers had significant improvement (Liu Xiaojuan, 2006). However,compared with other disciplines, high education level of College English teachers have a

Large gap, development is very uneven. Teaching conditions and teaching environment. With the advancement of education reform, the construction of infrastructure for all the colleges and universities are constantly improving, conditions and environment of College English teachinghas been improved. Many colleges and universities have the network computer room, to provideindependent learning opportunities for students.

\section{THE EXISTENCE OF CHINA'S COLLEGE ENGLISH TEACHING PROBLEMS}

\section{A. The lack of attention to college English Teaching}

Although the majority of our colleges and universities set up the course of College English, but many colleges and teachers did not attach great importance to college English Teaching in the teaching process, the existence of a perfunctory situation (Yu Li, 2014). Many colleges and universities are not the English curriculum as a key course for training, in addition to Englishmajors, and other professional students think college English curriculum is the extra burden,don't learn the material content.
B. The relationship between teachers and students has been unable to meet the psychological needs of modern college students.

relationship between teachers and students in traditional teaching mode of treatment often use improper College English class, with teachers' teaching,students' passive acceptance, not to form a good interaction with the teachers, dull atmosphere in the classroom. Affected by the traditional education ideas, teachers think they have the absolute authority in the teaching process, must keep a certain distance with the students, but the relationship between teachers and students has been unable to meet the modern college students' psychological needs.

\section{The teachers troop structure is unreasonable}

At present the construction of teachers' team in Universities of our country in the certain problems, there are many unreasonable phenomena in the structure of teacher team. UniversityChinese English teachers, mostly female teachers, male teachers in more than $80 \%$,only a very small part of the female teachers in teaching, will be more patient and careful, but because the female teachers face pregnancy problems, will arrange for the school teachingbrings certain influence. And College English teachers' age are lower, compared to olderteachers, although full of passion, but the lack of relevant teaching experience (Feng Ru, 2013).College English teachers of the professor is very few, most of them just participated in the work of the lecturer, difficult to complete the disciplines of scientific research work, and with the increasing of college enrollment, the number of College English teachers is obvious shortage,teaching task is very onerous. College English teaching reform and development direction according to the investigation and Research on the current situation of China's College English teaching, we can see there is still a problem in College English teaching, according to theplanning requirements of the program, combining the actual circumstance of the school, and further promote the University

\section{ENGLISH TEACHING REFORM, IMPROVE THE TEACHING QUALITY OF UNIVERSITY ENGLISH}

\section{A. Change the traditional teaching mode}

According to the present our country University in College English teaching, the actual situationis closely combined with the requirements of the new curriculum reform and the school itself,change the traditional teaching mode, a prominent position put students in teaching activities,improve the enthusiasm and initiative of students learning english. The university Englishteaching and computer network technology, improve the modernization level of English teaching,the use of multimedia teaching means, to carry out the new teaching mode, improve classroom interactivity, establish good relationship between teachers and students. Reasonable utilization of Internet information resources, create good 
teaching environment for students, to arouse students' interest in learning English in the university.

\section{B. To establish a scientific and reasonable system of university English Curriculum}

College English curriculum can usually be divided into professional English, general English andgeneral education in English, in addition to the professional class of English is not highcomprehensive application of the other English, but there are also a large part of the nonprofessional students English ability is very strong (Zhang Jiazheng, 2010). This requires the reform of College English teaching to establish a more comprehensive curriculum system, not only to impart English knowledge, but also improve the students' ability of using English in general.

\section{Strengthen the characteristic curriculum}

According to different regions, Chinese college students and the society also exist differenceson College English aspect demand, according to the different school category classification guidance to students, improve the applicability of students learning english. At the same time, according to the actual school itself, set with its own characteristics of the English curriculum, avoid every university curriculum are convergence, no features to speak.

\section{The construction of teachers' team of outstanding}

Reasonable structure of teachers, appropriate to hire an experienced senior college Englishteachers teaching activities, and promote the professional title structure of College Englishteachers reasonable, improve college English teachers' teaching and scientific research level.Promoting teachers professional quality and comprehensive vocational ability, improve the quality and level of College English teaching, to cultivate high-quality talents to adapt to thefierce international competition environment.

\section{SUGGESTIONS OF ENGLISH TEACHING REFORM IN UNIVERSITY}

At present, there is a great difference China between universities, by the economic, education and culture, the restricting factors of teachers, students and funding for soft, hardware, reformmode can not be identical. The author here also university English teaching reform in higher education and puts forward the following suggestion:

(1) the construction of relatively stable teaching team

Talent employment mechanism of the market is relatively vulnerable groups in Colleges and universities (colleges and in remote, underdeveloped area colleges and universities) is a great impact and challenge. Reform in any field, people are the most important factors. It is moreactive, more active, so is the university English teaching reform. No matter how advanced yourcomputer network, leave the teachers talk about educational reform is empty. Foreign language teachers is relatively liquid group. How to build a stable teaching team? First of all is the policy to keep people: at present foreign language public class teachers generally low academic qualifications, professional title structure relative most onerous task of teaching, further study opportunities, resulting in the ordinary university teachers loss. The school should take the positive main supporting policies and measures, the construction ofrelatively stable teaching team. Second is to keep people feeling: a technological and academicatmosphere is strong, deep culture school, the teacher always relatively stable.

(2) to fully tap the potential implementation of graded teaching teachers.

Here is a piece of the lush pastures, later many sheep, grassland degradation, water depletion,shepherd without resistance to catch the rest of the sheep to find it at the new meadow. The popularization of higher education makes the college as the degradation of grassland forCollege English teaching, especially for the. To solve the problem of widening the teacher-student ratio, we can consider the problems of development and utilization of moderninformation network. But it can only solve heard. In order to solve the problem of reading writing and translation, the author thinks that should be based on the (requirements "to take teaching in large classes, fully tap the potential effect of good teacher lectures. At the same time, vigorously promote the grading teaching, different level for students, teaching students according to their aptitude. Such not only can temporarily alleviate the teacher shortage problem, but also to maximize the potential of mining different levels of teachers and students, this is kill two birds with one stone.

(3) the full reasonable use resource of software and hardware

In order to cope with the reform of College English teaching, the software and hardwareresources necessary investment is a prerequisite. It's obviously just a tape recorder with teacherspeaking class model is unable to meet the requirements of today's teaching. But for teaching is very tight funding the University, the full realization of the multimedia network teaching is not realistic. Universities have of course should vote, to create first-class campus teaching network,no conditions can also be through the transformation of existing speech laboratory, adding newlanguage lab, multimedia language laboratory with local teachers classroom supplement andquantitative can also achieve the desired effect. So one of the full and rational use of software and hardware resources but also the reform of College English teaching should be the key issues to consider.

(4) the

strict teaching evaluation and examination stimulation system

The reform of teaching objectives, teaching methods and teaching content to meet the need ofevaluation system. The system of course should also reflect the personalized service, the overall goal of reform: to hear, how to assess the ability of listening and speaking? The importance of reading writing and translation, how to adjust the way of examination? Heard and read and write how to assign each accounted for the proportion of translation evaluation? So many of the number of students, and the multimedia 
teaching means are mediated, listening and speaking, reading writing and translation and after-school tutoring can online? Problems

of network facilities, technology management existence can keep up with the pace of reform? All these need the experts to explore in the future quite a long period of time. When it comes toteaching evaluation, here also discuss four, six level of test. Colleagues on four, six level of testviews, some good, some bad. Both viewpoints on how to talk, four, six level of test is the demand of the society, it just so there is recognition of the society, because this thing. Although the four,six level of test the university English to the exam oriented education, but we have to admit thatits role in university English teaching plays in the past years. The reform of teaching mode,teaching objectives and teaching means also calls for four, six level of test content, ways andmeans to reform, evaluation form the mutual stimulation mechanism.

The new teaching mode emphasizes the use of network technology, the application of multimedia teaching courseware occupies an important position. According to the results of the survey, the multimedia teaching courseware used by most schools provided by publishers, but there are also many universities had two times the development of courseware. Participate in the research school basically use the multimedia courseware aided teaching, but there are stillmore than half of the schools rely mainly on publishing courseware, this reflects a multimedia courseware publishing offers got most school accreditation, but excessive dependence onothers courseware may be difficult to satisfy the specific needs of the school and the classstudents, also cannot improve the teachers educational technology ability to effectively use.Further data analysis shows that, although a large number of school multimedia coursewaremainly use publishing offers, but the relative 211 Engineering Schools, in the 985 project and the 211 Project schools have more schools to develop their own teaching courseware. Their percentages were: 985 Engineering School (21.6\%), $211 \quad$ Engineering School (18.5\%), 211 Engineering Schools (5.9\%). This shows that the higher level schools pay more attention to the individualized teaching requirements of the school to a certain extent, the school teachers are also relatively strong. To participate in the research school, the school has about $2 / 3$ and the use of multimedia network resources database, but in a different school, source of its resource base are also different. The network resource database is more from the press, less by the school independent development. 985 engineering schools, 211 Engineering Schools and 211 Engineering Schools using the school independent development of network resources for theproportion were $23.5 \%, 21.9 \%$ and $6.5 \%$.

The reform of teaching evaluation is an important part of College English teaching reform, whichincludes evaluation of relation handle summative and formative assessment, especially toformative assessment in the teaching evaluation of the effect of strengthening. In addition, tocorrectly handle the national examination and the school assessment of oral test and written testthe relationship, the relationship between.

\section{REFERENCE}

[1] Feng $\mathrm{Ru}$ at Anhui University University under the research of [D]. public English teaching management reform in the network environment, 2013

[2] Liu Xiaojuan at Northeast Normal University University College English teaching reform of [D].research, 2006

[3] Sui Xiaobing. Under the network environment of College English classroom teachingoptimization of [D]. Shanghai International Studies University, 2013

[4] Yu Li. Study on teacher autonomy implemented in College English Curriculum: curriculum enactment perspective [D]. Shanghai International Studies University, 2013

[5] Ceng Xiaoshan. The implementation of College English Curriculum in the [D]. research of teachers' recessive courses of Shanghai International Studies University, 2013

[6] Zhang home. The reform of College English teaching and research of [D]. cultural philosophy, Southwestern University, 2010

[7] Chen Changqing. The teaching and research of [J]. language survey need technologylanguage society, 1984 (2).

[8] Ying Huilan. The syllabus design theory basis and social basis of [ $\mathrm{J}$. foreign language world,1996 (2)

[9] Xia Chunyan, Yan Xiaorong. Journal of social demand and the reform of College English teaching [J]. Chongqing University, 2003 (3).

[10]/The Department of higher education of [10] of Ministry of education. The College English curriculum requirements [S]. Beijing: Higher Education Press, 2007 